\title{
Metinlerarasılık Kapsamında G.O.R.A. ve A.R.O.G. Filmlerinin İncelenmesi
}

\section{Muge KALIPÇI ${ }^{1}$}

\begin{abstract}
Öz
Şüphesiz her bir eser kendinden önceki eserlerden birtakım izler taşır. 1960'lı yllarda başta Bakhtin ve Kristeva olmak üzere, Rifaterre, Genette ve Bloom gibi postmodern edebiyat kuramcları, metinlerin incelenmesinde metinlerarası ilişkileri merkeze yerleştirmişlerdir. İki veya daha fazla metin arasındaki hareketi belirtmek için kullanılan metinlerarasılık kavramı, postmodern olarak etiketlenen farklı disiplinlerde de uygulanmaya başlanmış olup zamanla günlük hayatın bir parçası haline gelmiştir. Bu teknikle geçmiş ile bugün arasında bağlantı kuran ve çeşitliliğin hakim olduğu eserler üretilmeye başlanmıștır. Ortaya çıktığı andan bu yana, sinema da, kendinden önceki sanatlarla başka bir esere gönderme yapma, alıntılama, parodi veya uyarlama gibi türlü biçimlerde iletişim içerisinde bulunmuştur. Metinlerarası teknikler kullanılarak oluşturulan filmler, geçmiş ile bugün arasında güçlü bir bağ kuran çok katmanlı bir yapı sergilemektedir. Cem Yılmaz, bilimkurgukomedi tarzında kurguladığı filmlerinde, birçok karakter, olay örgüsü ve atmosfer oluşumunda metinlerarası bağları ustalıkla kullanılmıştır. Bu çalışmada, G.O.R.A. ve A.R.O.G. filmleri, çeşitli sayıda filme yaptığı göndermeler kapsamında metinlerarasılık açısından incelenmiştir.
\end{abstract}

Anahtar kelimeler: Metinlerarasılık, G.O.R.A., A.R.O.G., Cem Yılmaz

\section{An Analysis of G.O.R.A. and A.R.O.G. in The Context of Intertextuality}

\begin{abstract}
Undoubtedly, each and every work has its own traces of previous works. In the 1960s, postmodern literary theorists such as Bakhtin, Kristeva, Rifaterre, Genette and Bloom, placed intertextual relations at the center when examining the texts. The notion of intertextuality, which is used to describe the movement between two or more texts, has begun to be applied in different disciplines labeled as postmodern and has become a part of everyday life. This technique has begun to produce artifacts that link the past and present and that are dominated by diversity. Since the day it emerged, cinema has alos communicated itself with previous arts in various forms, such as quoting, referencing, parodying, or adaptation to another artifact. Films created using intertextual techniques exhibit a multi-layered structure that links the past with today. Cem Yilmaz has skillfully used intertextual connections in the formation of many characters, plot and atmosphere in his films, which he created in the science fiction-comedy style. In this study, two films G.O.R.A. and A.R.O.G. have been examined in terms of intertextuality within the scope of connections they have made with other films.
\end{abstract}

Keywords: Intertextuality, G.O.R.A., A.R.O.G. , Cem Yilmaz

\section{Giriş}

Belli bir metnin, önceden yazılmış ya da söylenmiş olana açık veya örtülü bir cevap, bir başka metne yapılan atıf niteliği taşıması olarak özetlenebilecek 'metinlerarasılık', Bakhtin’in ‘diyalojizm' anlayışına

Okt., Erciyes Üniversitesi, Yabancı Diller Bölümü, mkalipci@yahoo.com [Makale kayıt tarihi: 28.9.2017-kabul tarihi: 11.10.2017]; DOI: 10.2900o/rumelide.347551 
dayanmaktadır. Metinlararasılık anlayışının fikir babası Bakhtin olsa da, bu kavram kabaca 1960'lı yıllarda Fransız kökenli eleştirel düşünür Julia Kristeva ile birlikte ortaya çıkmıştır. Bu anlayışa göre, genel olarak, tüm metinler diğer metin izlerini içerir ve metinlerarasılıktan kaçmak mümkün değildir. Bir başka bir deyişle, daha önce diğer metinlerde belirtilen birtakım fikir, kavram ve temalara değinmeyen bir metin yoktur. Bu anlamda, her metin çeşitli renk ve dokulardan oluşan, yaratıcı fakat orijinal sayılması zor bir patchwork çalışması olarak düşünülebilir. Metinlerarasılık kavramı, ilk olarak Kristeva (1969) tarafından adlandırılmış olup, herhangi bir metnin anlamını çıkarmak için bazı diğer metinlerle ilişkili olarak yorumlanması gerekliliği üzerinde durmaktadır. Tek bir anlama indirgenemeyecek olan metinlerarasllık kavramı farklı şekillerden ele alınabilir (Allen, 2011, ss. 11,21). Kristeva'nın metinlerarasılık yaklaşımı kavramsallaştırmasında, Saussure’ün ve Bakthin'in farklı şekillerde tartıştığı dilin ilişkisellği düşüncesi ve Bakhtin’in diyaloji kavramı önemli bir yere sahiptir. Aktulum metinlerarasılı̆̆ın gelişerek yayılmasında öncü isimlerden olan Kristeva'nın metinlerarası ilişkiye bakışını şu şekilde açıklar:

Bakhtin’in söyleşimcilik (diyalojizm) kuramını Fransa'da tanıtan Julia Kristeva, metinlerarası tanımını büyük ölçüde, onun çalışmalarına bağlı kalarak yapar. Nasıl ki söylem konuşanla dinleyenin karşılıklı etkileşiminin sonucuysa, önceki ve çağdaş ötesi sözcelere gönderiyorsa metinler de hep başka metinlere gönderir, başka metinlerin alanında yer alırlar. Sonuçta her metin bir alıntılar mozaiği, başka metinlerin bir dönüşümüdür. (Aktulum, 200o, s. 91)

Kristeva (1969) 'dan da anlaşılacağı üzere, bir metin alıntılardan meydana gelen bir mozaik olarak inşa edilir ve bir metnin toplam anlamı diğer metinlerle olan ilişkisine bağlı olarak oluşur. Metinlararasılık gerçeği göz önüne alındığında, hiçbir metnin diğer metinlerden bağımsız, kendi başına var olamayacağı görülür. Tüm metinler birbiriyle iç içe geçmiş olup, açık ya da örtülü olmasına bakılmaksızın birbirlerine referansta bulunmaktadır. Böylesi bir metinlerarası bağlamda, tamamen bağımsız ve izole edilmiş tek bir metin yoktur. Barthes için bir metini metin yapan onun sahip olduğu metinlerarası değerdir:

Herhangi bir metin, geçmiş atıfların oluşturduğu yeni bir dokudur. Kodun, formüllerin, ritmik modellerin, sosyal dillerin parçaları vb. metne geçer ve metin içerisinde yeniden dağıtılır; çünkü metnin öncesinde ve çevresinde her zaman dil bulunur. Metinlerarasılık, herhangi bir metnin durumu, tabii ki, yalnızca kaynaklara veya etkilenim sorununa indirgenemez; Metinlerarası, kaynağı neredeyse hiç bulunmayacak anonim formüller bütününü, tırnak işareti olmaksızın, farkında olmayarak veya otomatik bir şekilde yapılan alıntıları kapsayan gelen bir alandır ("Theory of the Text", s. 39).

Postmodern okumaların temel yöntemlerinden biri olan metinlerarasılık, bazı metinlerin diğer metinlere gönderme yapmak suretiyle anlatma yaratma metodu olarak da açıklanabilir. Her metnin bir şekilde kendi dışındaki diğer metinlerin 'yeniden yazımı' olduğunu ve diğer metinlerin varlı̆̆ının edebi metnin varlığını mümkün kıldığını savunan metinlerarasılık yalnızca edebiyat ile sınırlı değil, aslında hayatımızın her anında izlerine rastlanan bir olgudur.

Umberto Eco metinlerarasılığı, önceki metinlerin yeni metinler üzerindeki yansıması olarak tanımlarken, Rifattere okurun bir metnin diğer metinlerle olan ilişkilerini ortaya çıararak anlamlandırılmasını metinlerarasılık olarak görür. Her metin kendisinden önce yazılmış bir başka metinden beslenip geliştiği için, metinlerarasılık bir anlamda zorunluluktur denilebilir. "Hiçbir sözcük ne yenidir ne de yansız ama sözcük yaşamını sürdürmüş olduğu bağlamlarla, daha önceki söylenmişliğiyle doludur. Bu kuram metinlerarasılığın temelidir” (Öğeyik, 2008, s. 22) . Bakhtin ve 
Kristeva'nın yanı sıra Barthes, Rifatterre, Bloom ve Genette gibi teorisyenlerin çalışmalarıyla, metinlarasılık postmodern dönemde edebi çözümlemenin temel kavramlarından biri haline gelmiştir. Metinlerarasılık, daha önce yazılan metinlerin okuyucuda yarattığı beklentiden yola çıkarak, yeni hazırlanan bir metnin anlamını oluşturmak olarak tanımlanmaktadır. Kavram aynı zamanda, yazarın daha önceki metni ödünç alıp değiştirmesi ya da okuyucunun bir metni okurken diğer metinle ilişki kurması anlamında kullanılmaktadır (Akser, 2010, s. 37). Barthes'a göre ise metinlerarasılık 'yazarın ölümü', 'okuyucunun doğumu' demektir. Çünkü esere anlamını veren zaten halihazırda var olan düşünceleri, yazılmış eserleri harmanlayarak bir ürün ortaya koyan yazar değil, bu yapıtı okurken kendi birikimlerinden yola çıkarak diğer her türlü metin ve olguyla bağlantı kuran ve metinle söyleşimsel etkileşim içerisinde bulunarak çıkarımlarda bulunan okuyucudur.

Bir metindeki tüm metinlerarası işlevlerin; alıntıların, anıştırmaların, yansımaların ve tüm yeniden yazma yöntemlerinin anlamlarını saptamak neredeyse olanaksız ve gereksiz bir çabadır. Okuyucu ekinsel durumuna ve metnin bağlamına göre metnin çözümleyebildiği kadarını algılamaktadır ve burada okuyucu edilgen değil daha etkin bir yapı içerisindedir (Aktaş, 2011, s. 54).

Metinlerarasılığın kaçınılmaz olduğu ve dolayısıyla her metnin melez bir nitelik barındırdığı bir dünyada, metinsel başarı, büyük oranda birbirine bağlı ya da birbiriyle kaçınılmaz ilişki içerisinde bulunan metinlerin bütünün oluşturduğu bir olgudur denilebilir.

Metinlerarasılık çalışmalarında vurgulanmak istenen temel nokta hiçbir eserin saf, bağımsız, tam anlamıyla özgün olmadığıdır. Her bir nesne, olay, düşünce, durum, olgu, yapıt birbirinden etkilenerek ve yine birbiriyle ilişkili olarak ortaya çlkmaktadır. Metinlerarasılık gerçekte okurun algısıyla ilgilidir. Metinlerarasılık okurun metinde kendi yansımalarını, kendi okurluk düzeyinin geçmişini, geleneğini, kaynaklarını, duygu ve düşünce dünyasını bulduğu oranda açığa çıkmaktadır. Metinlerarasılık ile "yeryüzünde söylenmemiş bir söz yoktur" ilkesince bütün zaman ve mekânları, tüm metinleri birleştirerek okuma eylemi gerçekleşmelidir. Bu okuma eyleminde okur hem metni hem de kendi zihnindekileri zaman, mekân, insan unsurlarını aşarak birleştirir ve anlamlandırır (Kılınçarslan, 2016, s. 52). "Kristeva'ya göre metinlerarası, bir metnin önceki bir metni yinelemesi değil, sonsuz bir süreç, metinsel bir devinimdir. Metinlerarası başka bir metne ait unsurları taklit etmek ya da onları olduğu gibi yeni bir metne sokmak işlemi değil, bir yer ya da bağlam değiştirme (transposition) işlemidir. Öyleyse metni hep bir metinlerarası görüngüde tanımlayan Kristeva'ya göre metnin metinlerarası olmasının nedeni, onun alıntılanan ya da taklit edilen başka unsurları kapsaması değil, onu üreten yazının önceki metinleri bozup bir yeniden dağılım işleminden geçmesindendir (Aktulum, 2000, ss. 4344)". Metinlerarası ilişkinin en bariz şekli olarak, bir metinde başka metine ait kesitlerin yüklendiği yeni anlamlarla var olması olarak adlandırabileceğimiz 'alıntılar' gösterilebilir. Diğer bir biçim olarak da, direk bir alıntı yapmaksızın kişilerin bireysel çaba ve birikimleri sonucu algılayıp keşfedebilecekleri bağlantılar olarak kendini gösteren "gönderge’lerden bahsedilebilir.

\section{Filmlerde Metinlerarasılık}

En basit ifadeyle bir metnin daha önce yazılmış bir metinle kurduğu ilişki olarak tanımlanan metinlerarasılık kavramının günümüz bağlamında daha geniş bir anlama sahip olduğu söylenebilir. 1960'lı yllarda postmodern okumaların temel yöntemlerinden biri olan metinlerarasılık kavramı, sanat alanında farklı disiplinlerin birbiriyle iç içe geçmeleri sonucu anlam çokluğu bağlamında geniş bir alanı kapsamaktadır (Önal, 2013, s. 108). Kutsal kitaplardan bu yana var olan metinlerarasllık, zaman, mekân ve biçim tanımaksızın hayatın her alanında gözlemlenebilecek bir olgu niteliğindedir. Kristeva’ya göre 
metinlerarasılık kavramı, bir metinde başka bir metnin edebi ve etkin varlığını ifade eder. Kristeva metnin kendisini, metinlerin bir permütasyonu, belirli bir metinde diğer metinlerden alınan birkaç alıntının birbiriyle kesiştiği ve birbirlerini etkisiz hale getirdiği metinlerarasılık olarak tanımlar (Allen, 2000). Sinema alanında metinlerarasılık bir filmdeki sahnenin başka bir filmde olduğu gibi kullanılması ya da türlü şekillerle o sahneye gönderimlerde bulunulmasıdır (Edgar-Hunt ve diğerleri, 2012, s. 70). Fransız film kuramcısı Bazin, prensipte tüm filmlerin belirli zamanlarda, belirli teknik ve estetik araçlarla sinematik bir sanat eseri yaratmayı başaran yazarların yapıtları olduğunu söyler (Barthes, 1957). Filme dönüştürülerek yeniden hayat verilen eserlere Shakespeare'in Romeo ve Juliet, Venedik Taciri, Hamlet, Othello gibi oyunları örnek verilebilir. Çağdaş film kuramcılarının lideri Christian Metz, filmlerin yalnızca birer sanat eseri değil, aynı zamanda da kendi orijinal, tekil bütünlügünü oluşturan yazılı bir sistem olduklarını ileri sürmüştür. Alman göstergebilim uzmanı Christian Metz'e göre, teknolojik ya da mekanik olsun, edebiyattan uyarlama, resim, renk, ses, ve hareket filmi teknik bir metinlerarasılık haline getirir. Diğer bir deyişle, film çoklu ortam içerisinde birbiriyle etkileşime geçerek ve birbiriyle kurduğu bağlantılar sebebiyle anlam kazanan bir araçtır.

Postyapısalcı edebiyat eleştirisinde bir metnin ancak diğer metinler ile kurduğu ilişkiler çerçevesinde varolabileceğini savunan metinlerarasılık, postmodern medya anlayışı kapsamında da egemen olup tıpkı yazılı metinlerde olduğu gibi görsel ve işitsel metinlerin de benzer metinler ile ilişki içerisinde olabileceği anlamına gelmektedir. Dilin iletişimsel, ilişkisel yapısından kaynaklanan bu etkileşim kaçınılmazdır. Her zaman bariz bir şekilde görünmese de, her medya metni çevredeki dünyadan etkilenir ve filmlerdeki metinlerarasılık yaratıcılıkla yakından ilgilidir. Bir metnin kaynağı, içerdiği konuşmalar ve temalarının diğer metinlerle nasıl bir iletişim içerisinde olduğunu iyi anlamak bu nedenle son derece önemlidir (Charaudeau \& Maingueneau, 2004, s. 288). Okuru anlam yaratma sürecine etkin olarak katan ve anlam yaratma gücünü yazarın tekelinden alan metinlerarası yaklaşım, görsel-işitsel medyada seyirciyi anlam yaratma sürecine dahil etmek şeklinde gerçekleşmektedir. Görsel, işitsel veya yazılı her türlü metnin diğer metinlerle etkileşerek, karşılıklı referanslarda bulunarak oluşturduğu çok katmanlı ilişki, her okuyucu ve izleyici için farklı çıkarım ve gerçeklikler yaratacaktır (Ott\&Walter, 2000, s. 430). Bir metnin başka metinlere gönderme yapması; oradaki bir kurguyu, karakteri ya da çatışmayı yeniden üreterek model alması metni teknik olarak zenginleştirir (Bars, 2013, s. 184). Bugün, film endüstrisindeki sonsuz dizi ve filmin yeniden şekillenme, yeniden doğuş ve uyarlamalarından oluşan yeni bir metinlerarasılık kavramından söz etmek mümkün gibi duruyor.

\section{G.O.R.A. ve A.R.O.G. Filmlerinde Metinlerarasılık}

Bu çalışmada senaryosu ünlü güldürü ustası Cem Yılmaz tarafından yazılan G.O.R.A. ve A.R.O.G. filmlerinin metinlerarası ilişkiler kurduğu yerli ve yabancı filmler tespit edilerek, bu ilişkilerin nasıl kurgulandığı incelenmiştir. Cem Yllmaz postmodern metinlerin önemli bir özelliği olan parodik referanslardan faydalanmak suretiyle hikayesinin tam ortasına Türk bir karakteri yerleştirerek özellikle Amerikan bilim kurgu filmlerini tiye almaktadır.

\subsection{G.O.R.A. : Bir Uzay Fìlmi}

G.O.R.A. senaryosunu Cem Yılmaz’n yazdığı, yönetmenliğini Ömer Faruk Sorak'ın yaptığı 2004 yılında vizyona girmiş bilim kurgu, macera, komedi türünde bir filmdir. "Uzayda bir Türk" fikri, Cem Yılmaz'ın Bir Tat Bir Doku stand-up şovundan bir bölüm üzerine kurulmuştur. Film, halı ticareti ile uğraşan ve UFO'lara büyük merak duyan Arif in uzaylılar tarafından G.O.R.A. adlı gezegene kaçırılmasını konu almaktadır. Arif gezegenine geri dönmenin bir yolunu bulmaya çalışırken, Prenses Ceku'ya aşı olur. 
Arif, gezegeni G.O.R.A.'nın kötü komutanından kurtarır ve böylece insanlar için bir kahraman haline gelir.

G.O.R.A., Türk film endüstrisi için şimdiye kadar yapılmış olan en büyük film seti, Türk filmleri arasında zamanının en yüksek bütçeli yapımı ve yapım şirketiyle yaşanan sıkıntılardan dolayı en uzun süre beklenen film olma özelliklerine sahiptir. Cem Yılmaz’ın kendisinin de dört farklı rolde yer aldığı "Türkler uzayda" sloganıyla tanıtılan bu film, metinlerarası özellikler bakımından oldukça zengin olup, kurulan bu metinlerarası ilişkiler birçok sahnede komedi unsuru olarak kullanışmıştır. Filmin çift-DVD özel baskısı üzerine yapılan röportajda Cem Yılmaz, filmin başlığının bir kısaltma olmadığını, ancak sosis ve salam ile yapılan bir çeşit popüler Türk sandviçinin isminden esinlendiğini açıklamıştır ve dolayısıyla filmin sonunda Arifin hikayesine inanmayan UFO dergisi editörü tarafından sipariş edilen "goralı" sandviç bu duruma referans olarak kullanılmıştır.

G.O.R.A. filminin esin kaynağı olarak, kendisi de bir zamanların popüler televizyon dizisi Uzay Yolu' ndan etkilenmiş olan Turist Ömer Uzay Yolunda (1973) kabul edilebilir. Turist Ömer Uzay Yolunda filminde de uzaylılar tarafından kaçırılıp bir uzay gemisinde hapsedilmiş olan bir dünyalının evine geri dönme çabası anlatılmaktadır. Arif'in başından geçen tuhaf olaylar Turist Ömer'in yaşadıkları ile benzerlik göstermektedir. G.O.R.A.'da Ceku'nun ağlayarak izlediği Şakayla Karışık filminde ekranda Sadri Alışık’n gösterildiği sahne Turist Ömer gibi tipik, içten bir Türk olan Arif'in uzay maceralarının anlatıldığı bu film ile Sadri Alışık filmlerindeki ana karakter saflığı arasındaki bağlantıyı yansıtan açık bir referans noktası olarak kullanılmaktadır.

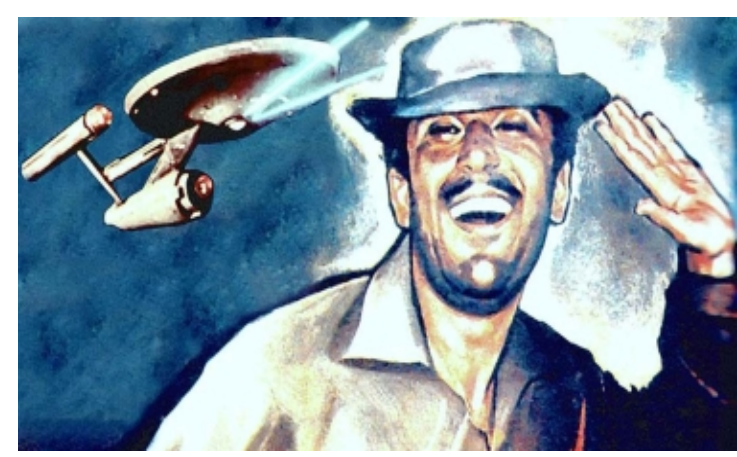

Turist Ömer Uzay Yolunda

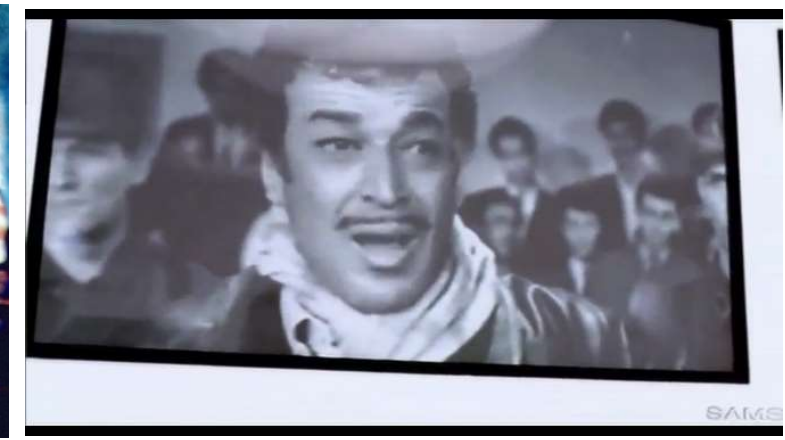

G.O.R.A. / Şakayla Karışık

Bu film postmodern metinlere özgü birçok unsur barındırmakla beraber, hem Türk sinemasından hem de dünyada büyük ilgi uyandırmış bilim kurgu filmlerden alıntılar yapmıştır. Cem Yılmaz filmde öncelikle kendi hayatına birtakım göndermelerde bulunmaktadır. Örneğin, Arif'in doğum tarihi olan 8 Aralık 1968 aslında Cem Yılmaz'ın kardeşi Can Yılmaz'ın gerçek doğum tarihidir. Ayrıca, Arif, Cem Yılmaz'ın babasının adı, Ceku büyükannesinin takma adıdır. Mulu, annesinin teyzesinin lakabı, Garla ise dedesinin Cem Yılmaz'a taktığı isimdir.

Cem Yılmaz, eğlence ve güldürü kültüründe etkili bir yere sahip olan kelime oyunu tekniğini kullanarak seyircinin kendi bilgi birikimi ve dikkatine dayanarak çeşitli bağlantılar kurabileceği bazı göndermelerde bulunmuştur. Örneğin, Garavel'in Arif'e sunduğu uzay gemisi "KA-FA 1500", 'keyif verici madde etkisi altında', anlamına gelen bir Türkçe argo terim olan'kafası güzel' için kullanılmıştır. Bir diğer örnek olarak, Sean Connery'den esinlenmiş Erşan Kuneri karakteri verilebilir. 


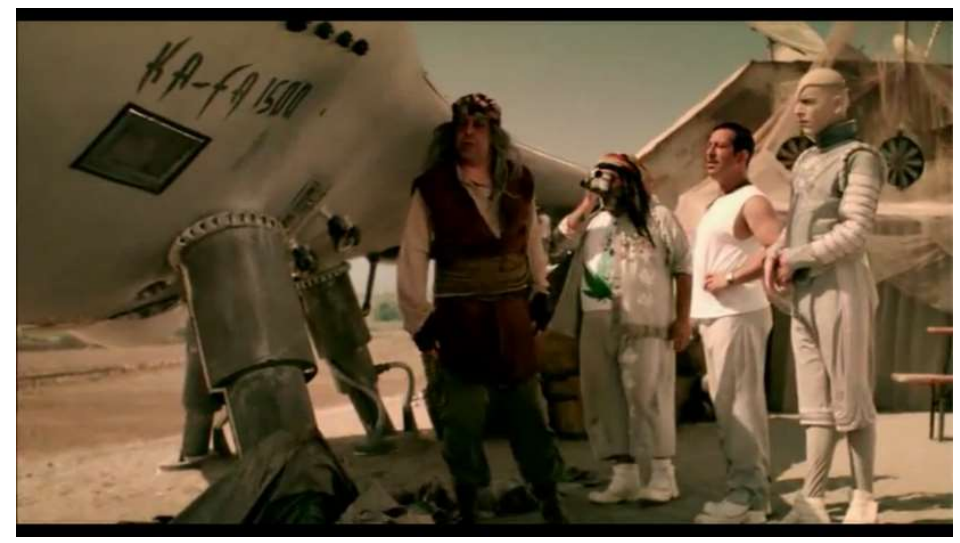

G.O.R.A. / "KA-FA 1500"

Macera-bilimkurgu-komedi türünde çekilen G.O.R.A., başta bilim kurgu kategorisindeki Matrix, Yıldız Savaşları ve Beşinci Element gibi filmler olmak üzere bir çok eserle metinlerarası bir ilişki içerisindedir. Arif hapishanede satranç oynarken satranç parçaları, temsil ettiği Picard, Riker, Data, Worf ve Dr. Crusher gibi karakterler ile, Uzay Yolu: Yeni Nesil filmini akıllara getirmektedir. Aynı şekilde, bilim kurgu kategorisinde en bilinen filmlerden biri olan Yıldız Savaşları serisine yapılan çok sayıda referans mevcut olmakla beraber, aralarında en belirgin olanı Arif'in duş aldığı ve o esnada Garavel'i Lucas'ın Y̌ldız Savaşları: Bölüm IV - Yeni Bir Umut (1977)'daki sahne kullanımına benzer şekilde gördügü sahnedir. Işın kılıcı ve kapüşonlu bir adamın hologramı gibi yinelenen görüntüler Yıldız Savaşları: Bölüm V-İmparatorun Dönüşü (1980) filmine yapılan göndermeler niteliğindedir. Arif, kaçırıldıktan sonra cep telefonu aracılı̆̆ıyla arkadaşını aradığında arkadaşının çocukları Space Invaders video oyununu oynamaktadırlar. Benzer şekilde, filmde bilim kurgu filmlerinden söz edilirken, 20o1: Bir Uzay Destanı filminin adı geçmektedir. Filmde Arifin, G.O.R.A. gezegenini ateş topundan korumak için dört element artı beşinci unsur olarak bir kızı kullanması Beşinci Element filmiyle bir bağlantı oluşturmaktadır. Söz konusu referans kaynağı, Beşinci Element filmini izleyen Arif'in bu filmden edindiği bilgileri kullanarak ateş topunu durduracağını dile getirmesiyle açıkça belirtilmiş oluyor.

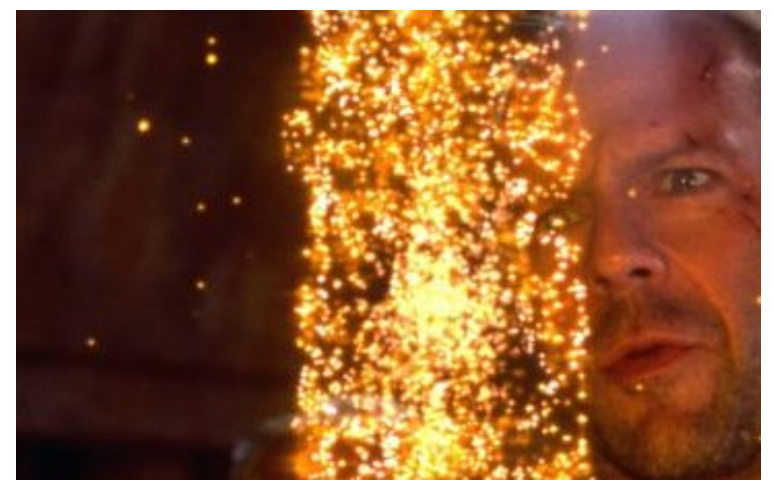

Beşinci Element

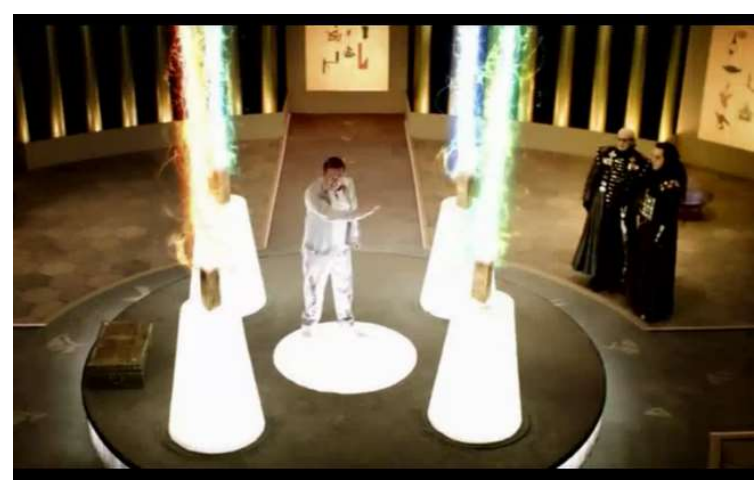

G.O.R.A.

Hollywood bilim kurgu filmlerinin en temel özelliklerinden biri olan özel efektler ve kamera oyunları, basit yöntemler kullanılarak taklit edilmiş ve güldürü unsuru oluşturulmuştur. Arifin usta Garafel ile karşılaşıp tanışmasını takiben birçok sahnede Matrix filminden çeşitli alıntılar yapılmış, Morpheus ile Neo arasındaki usta ve öğrenci ilişkisi taklit edilmiştir. Neo gibi Arif de seçilmiş kişidir ve bu gerçek ona yüklediği dövüş sanatları gibi çeşitli becerilerle onu büyük mücadeleye hazırlayan Garafel tarafından 
sıkça dile getirilmektedir. Matrix’te sanal aleme geçiş aracı olarak kullanılan mavi ve kırmızı haplar, G.O.R.A.'da parodi unsuru olarak kullanılmaktadır. Ayrıca, Arif'in ışın saçan bir silahtan gelen kurşunla sigarasını yakmak için arkaya doğru eğildiği sahne Matrix filminde Neo'nun sergilediği ünlü slow motion sahnelerini akıllara getirmektedir. Matrix'te, Neo'ya bir takım bilgi ve beceriler yükleyen büyük süper bilgisayarları görmüş olan sinema izleyicileri, G.O.R.A.'da bunu yapmak için bir bilgisayar klasiği olan Commodore 64 kullanılarak Matrix filmi ile bir bağlantı oluşturulmuş olduğunu da açıça görebilmektedir.

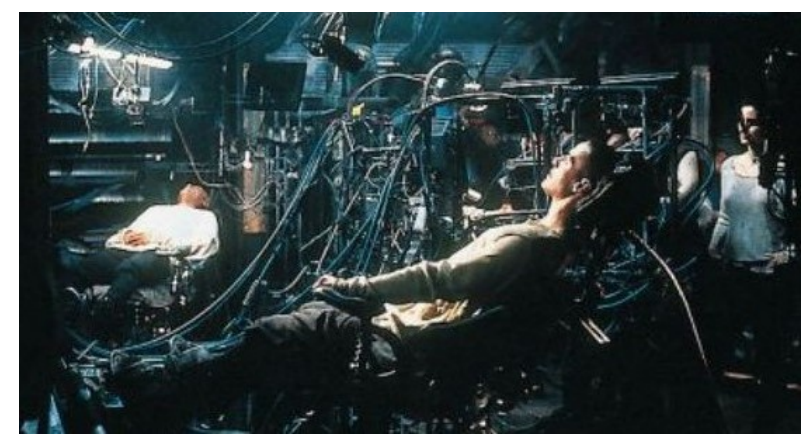

Matrix

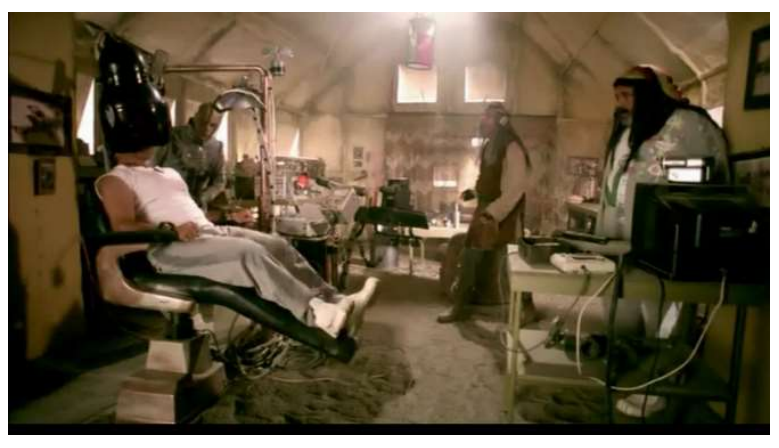

G.O.R.A.

Arif in, Kaplan ve Ejderha'da olduğu gibi, tek ayağının üstünde durduğu sırada ağaçtan meyve kopardığı bir sahne bulunmaktadır. Garavel ustanın, Arif'in eğitiminin bir parçası olarak ona evini boyatma, meyve toplatma gibi gündelik işler yaptırdı̆̆ sahne de Karateci Çocuk(1984)'a yapılan bir göndermedir.

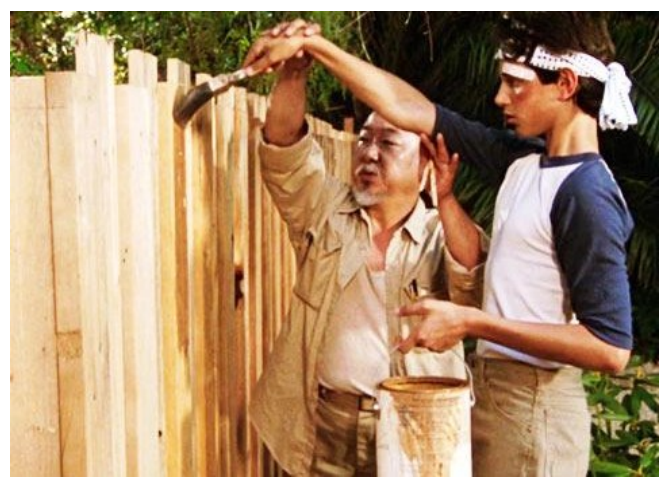

Karateci Çocuk

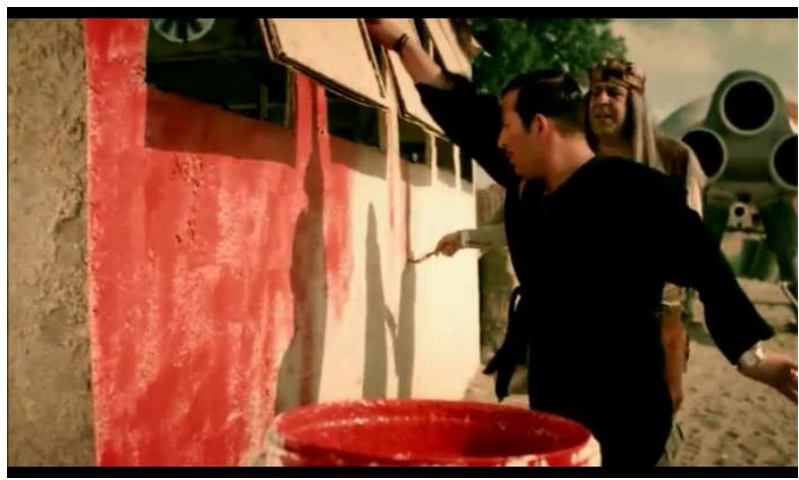

G.O.R.A.

G.O.R.A. filminde, çeşitli eserlere çoğu kez doğrudan isim verilerek ya da birtakım görsellerle atıfta bulunulmaktadır. Örneğin, duvarda bulunan bol sayıdaki James Bond posterleri Dr. No (1962) filmine bir referans niteliğindeyken, Arif'in bir mahkûmdan gülü aldıktan sonra kendisi ile arasında geçen diyalogda The Cosby Show (1984) televizyon dizisi izleyicilere hatırlatılmaktadır. Uzaydan dünyaya dönerken geçirdiği kaza sonucu bedeninin büyük bir kısmını kaybeden ancak yeniden hayata döndürülen Albay Steve Austin'in hayatını anlatan ve biyonik adam ekolüne öncülük eden yapıtlardan biri olan 6 Milyon Dolarlı Adam (1974-1978) adlı televizyon dizisine de göndermede bulunulmaktadır.

Cem Yılmaz ana karakter Arif aracılığıyla, uzaylıları istenmeyen, çirkin ve kötü niyetli, insanların düşmanı olarak konu edinen E.T., Yasak Bölge 9 ve Yaratık serisi gibi yabancı filmlere atıfta 
bulunmaktadır. Arif, seyirciye yönelik yaptığı bir konuşmada "Amerikan sineması sözüm sana. Yıllarca uzaylıyı başka tanıttın. Onu bir öcü gibi gösterdin! Ama unutma; uzaylı da olsa insan, insandır.” diyerek Hollywood sinema sektörüne bir eleştiri yapmaktadır.

Referans noktası olarak kullandığı Hollywood bilim kurgu filmlerini bir komedi filmi yaratabilmek adına tamamen farklı bir bağlamda yeniden değerlendiren Cem Yılmaz, A.R.O.G. yerel kültürün temsilcisi olarak sunduğu bir Türk karakter üzerinden ortaya başarılı bir metinlerarasılık örneği olan bir komedi filmi çıkarmıştır.

\subsection{A.R.O.G.: Tarih Değişiyor}

G.O.R.A.'nın devamı niteliğinde çekilen ve 2008 yılında "Bir Yontma Taş Filmi” sloganı ile gösterime giren A.R.O.G. ilkçağlarda geçmektedir. Senaristliğini Cem Yılmaz’nn, yönetmenliğini Cem Yılmaz ve Ali Taner Baltacı'nın ortaklaşa üstlendiği ve bilimkurgu parodisi üzerine şekillenmiş fantastik komedi türünde bir dönem filmi olan A.R.O.G.'da, Komutan Logar Arif'i kandırarak zamanda 1.00o.ooo yll geriye gönderir ve Arif, geçmişten bugüne ulaşabilmek için ilkçă̆ insanlarını uygarlaştırmalıdır. G.O.R.A.'da olduğu gibi A.R.O.G.'da da parodi stili ağırlıklı olarak kullanılmakta olup, film farklı metinlerle kurduğu ilişkiler açısından, izleyiciyi anlam çıarma ve bağ kurma sürecine etkin olarak katan zengin bir içeriğe sahiptir.

Filmin konusu göz önünde bulundurulduğunda, 2001: Bir Uzay Destanı (1968) ve Jurassic Park (1993) filmleriyle yoğun metinlerarasılık içinde bulunan A.R.O.G., söz konusu filmlerdeki sahnelerin uyarlanması aracılığıyla hikayesini anlatmıştır. Komutan Logar tarafından kandırılarak, 1.00o.ooo yıl öncesine gönderilen Arif, burada ilk olarak maymunlarla karşılaşmakta ve maymunları eğiterek ait olduğu ileri medeniyete dönebileceğini ummaktadır. Arifi'in maymunlara öncelikle iki ayak üzerinde durarak başlayacaklarını ve medeniyete ulaşmaları gerektiğini açıkladı̆̆ı sahne Charles Darwin'in Evrim Teorisi ile bağlantı teşkil etmektedir. Filmin sonuna doğru Arog halkına veda ederken Arifin "Maymundan gelmedik belki ama maymuna gidiyoruz" cümlesi de toplumsal bir eleştiri niteliği taşımaktadır. Maymunları medenileştirme çabasında başarılı olamayacağını anlaması üzerine Arif, maymunların yanından ayrılır ve Arifin sahneyi terk etmesini takiben gökyüzünden düşen siyah bir monolit maymunların önünde belirir. Bu cisim 2001: Bir Uzay Destan (1968) filmine göre maymunların gelişmesini sağlayacak bir aracıdır ve A.R.O.G.'da Arifi'in maymunlardan sonra karışılacağı insanları medeniyete ulaştırma çabası esnasında söz konusu film ile kurulan bir metinlerarası bağlantı niteliğindedir.

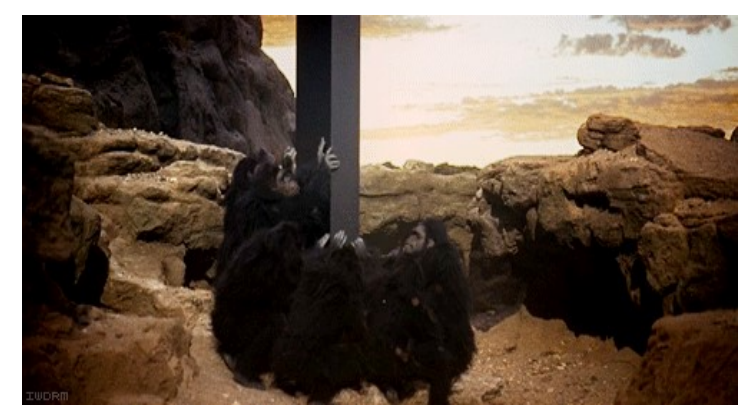

2001: Bir Uzay Destam

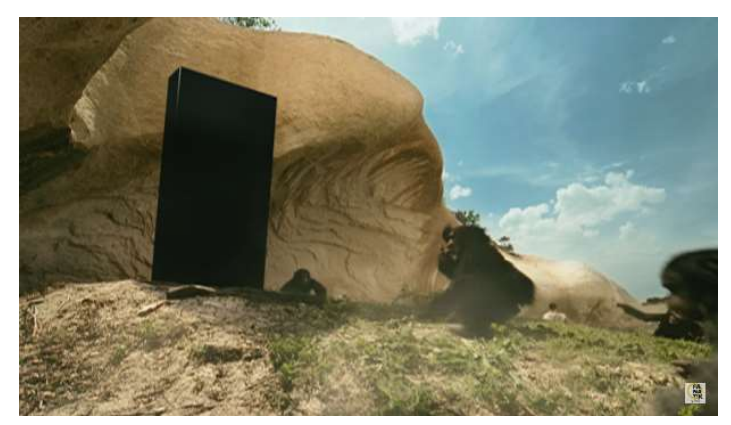

A.R.O.G. 
Barthes tarafından yazarın ölümü olarak adlandırılan, okuru / izleyiciyi anlamlandırma sürecine aktif olarak katan postmoderen yaklaşımlarda, mevcut metinlerarası bağlantıların kurulabilmesi büyük ölçüde okurun/izleyicinin bilgi ve deneyim birikimine dayanmaktadır. Dolayısıyla, bahsi geçen referans ancak söz konusu filmi izleyen veya bu sahneden haberdar olan izleyiciler tarafından anlaşlabilecektir.

Arif in dinozorla karşılaştığı ve "Abi bütün filmlerinizi izledim. Jurassic 1, Jurassic 2, Jurrasic 3. Lütfen" repliğini söylediği sahne açıç̧a ve birebir Jurassic film serisiyle yakından bağlantı oluşturmaktadır. "Seni bilgisayarla yapıyorlar, piksel piksel ederim seni" diyerek yine Hollywood sinema sektörünün kullandığı özel efektleri tiye almaktadır.

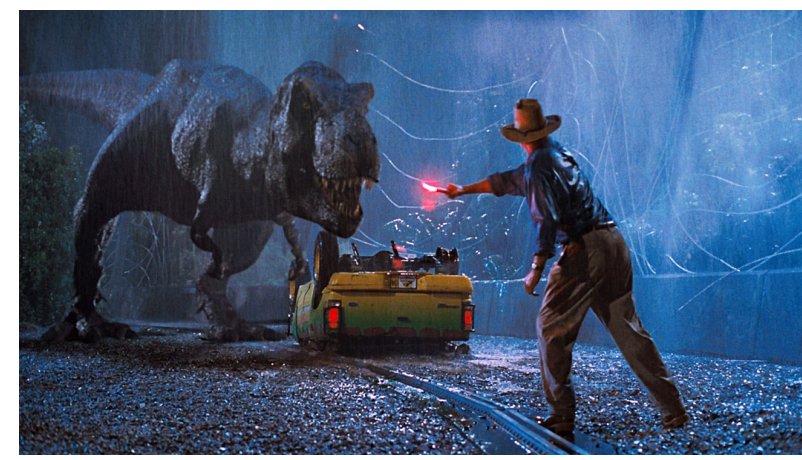

Jurassic Park

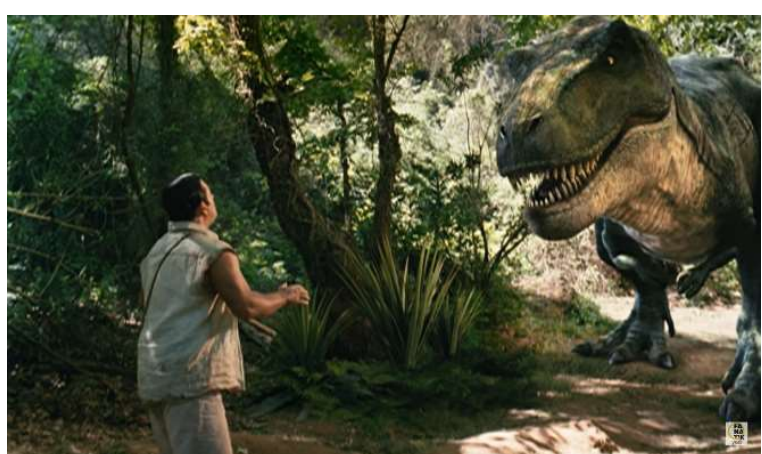

A.R.O.G.

Bunun yanında Yüz Yüze, Azınlk Raporu, Gözleri Tamamen Kapal, Hayalet gibi Hollywood filmlerine de birtakım sahnelerde açıktan ya da dolaylı olarak referans verilmiş olup, yine bu atıflar olay örgüsü içerisinde güldürü unsuru olarak yer almıştır. Örneğin, Taşo ile Mimi’nin seramik yaparken Arif'in Taşo'ya "Patrick Swayze" olarak atıfta bulunduğu sahne Hayalet (1990) filmine yapılan bir göndermedir. Bu filmle kurulan ilişki Arifin habersiz gelişini “Hayalet gibi geldim dimi?” olarak belirtmesiyle pekiştirilmektedir.

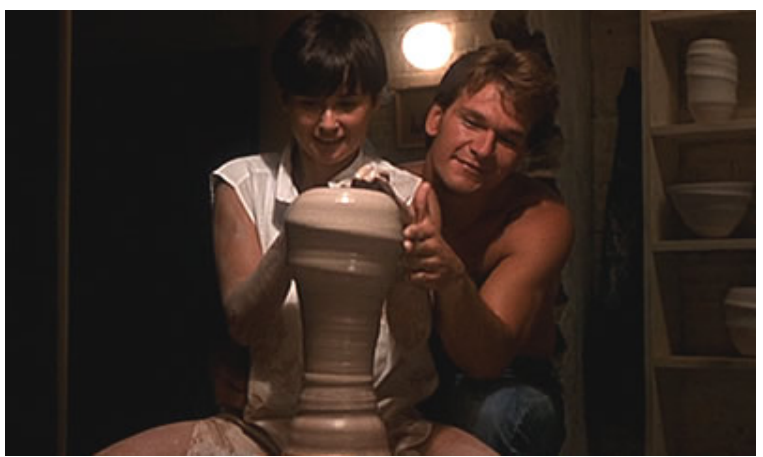

Hayalet

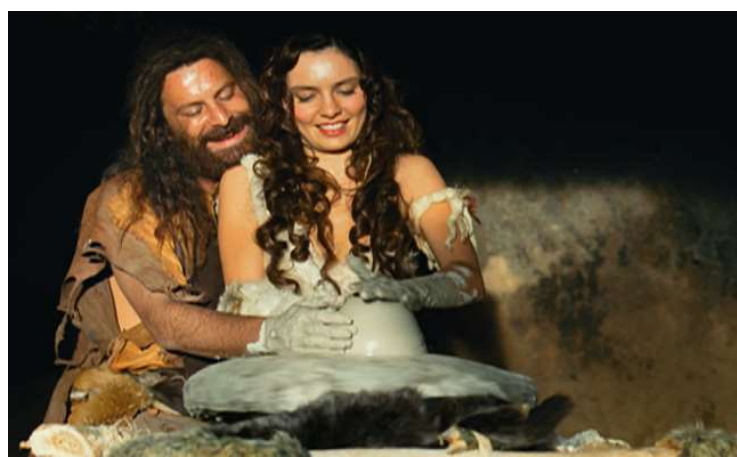

A.R.O.G.

Komutan Logar, Arif in halıcı dükkanına izinsiz girdikleri sahnede, kendisinden daha önce yaşananlar için özür dilerken hapisten "Dahşan affı" ile çıtıklarından bahsetmektedir. Kelime oyunu ile yerel kültüre ait siyasi bir göndermede bulunan Cem Yılmaz, izleyiciye Türk siyaset tarihinde Rahşan Ecevit’in önerisi ile yürürlüğe giren ve Rahşan Affı olarak bilinen Şartla Salıverme ve Erteleme Yasasını hatırlatmaktadır. Yine aynı sahnede Arif in slow motion tekniği ile havada durduğu sahne akıllara Matrix’i getirmektedir. 
Komutan Logar Arifi kaçırdıktan sonra görünüş olarak ona benzeyebilmek ve dolayısıyla Ceku’yu kaçırıp G.O.R.A.'ya geri götürebilmek için dış görünüşünden birtakım değişikler yapar. Kıyafetlerini "clothes off” yöntemiyle Arife benzettiğini söylerken burada ufak bir kelime oyunuyla izleyicilere Yüz Yüze (1997) filmi çağrışımında bulunmaktadır. Yine teknolojiden istifade eden Komutan Logar'ın Arife benzemek için yüzünü değiştirdiği sahnede açıkça "face off" tekniğini kullanacağını söylemesi Yüz Yüze(1997) filmindeki yüz değiştirme sahnesini akıllara getirmektedir.

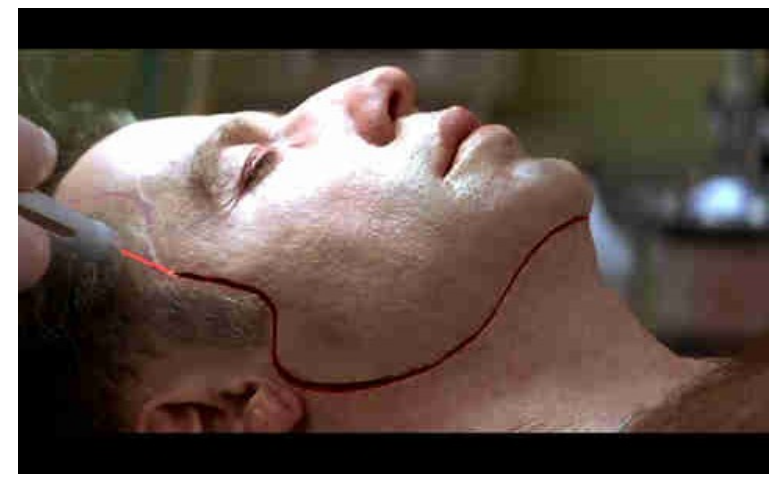

Yüz Yüze

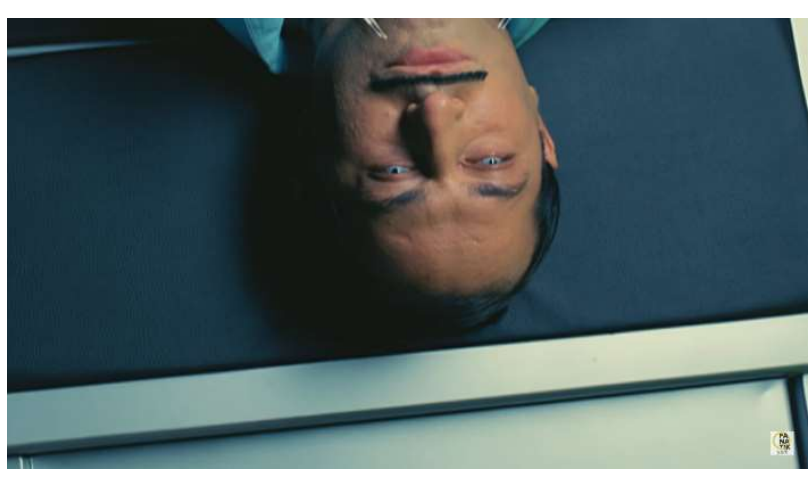

A.R.O.G.

Logar'ın, sesini değiştirmek için söylediği "Bana şu Tom Cruise'un filmde kullandığı aleti ver" ifadesiyle yine Azınlık Raporu (2002) filmine bir referans noktası oluşturulmaktadır. Sesini değiştirmeden hemen önce Logar kısa bir süre yanlışlıkla Tom Cruise'ın balo sahnesindeki maskesini takarak, Gözleri Tamamen Kapah (1999) filmini akıllara getirmektedir.

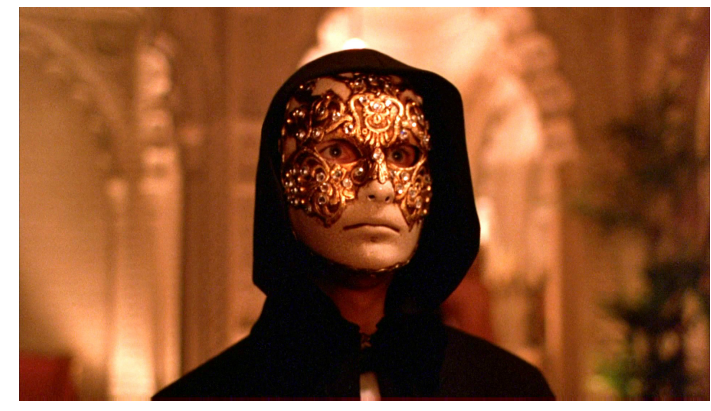

Gözleri Tamamen Kapal

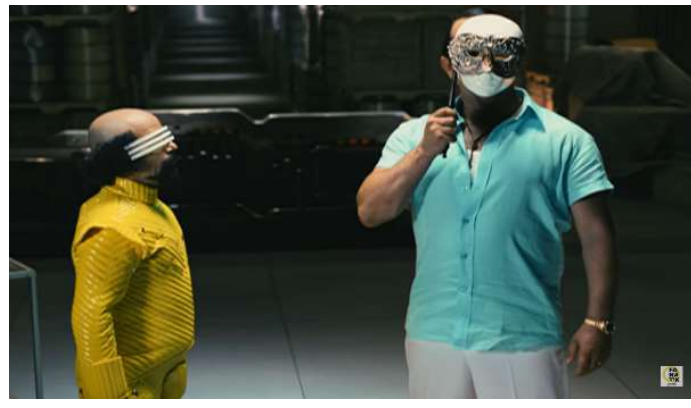

A.R.O.G.

Cem Yılmaz aynı sahnede "Seni çok seviyorum yavrum, yarın gelip seni babandan isteyeceğim" repliğiyle Yeşilçam sinemasına göndermede bulunuyor ancak bu metinlerarası bağlantı yer aldığı sahne itibariyle yalnızca bir güldürü unsuru olarak kullanılmıştır. Benzer bir gönderme Aroganlıların sık sık kullandığı "Yalan, yalan söylüyorsun" cümlesinde görülebilir. Bir başka yerel bağlantı da Logar’ın Arifi "Küfür etme. Küfür yok. Çocuklar izliyor." seklinde uyarması ile Cem Yılmaz’ın film ve standup gösterilerine bazı kesimlerce yapılan uygunsuz dil içermesi yönündeki eleştirilerdir. Mahkumların Aroganlılar tarafından cezalandırılacağı sahnede Arif, "Mel Gibson'un çektiği film gibi olmasın bu? Kafa kesmeli falan. Tanrılar kurban istiyor falan olmasın" repliğiyle Mel Gibson'nn Maya uygarlığı hakkında çektiği 2006 yapımı bir film olan Apocalypto'ya referansta bulunmaktadır.

Bir komedi filmi olan A.R.O.G. güldürü unsuru olarak Hollywood sineması ile kurmuş olduğu metinlerarası bağlantıları ustalıkla kullanmaktadır. Gerek bilimkurgu, macera türündeki popüler 
filmlerin izleyicileri tarafından oldukça iyi bilinen sahnelerin absürt bir biçimde kopyalanması ve yeni gerçekliğine oturtulması, gerekse karakterlerin ilgili filmlerin adını birebir anması şeklinde metinlerarası bağların kaynakları izleyicilere sunulmaktadır.

\section{Sonuç}

1960'larda edebiyatta, 70'li ylllarda mimaride ve 80'lerde sinemada ortaya çıkan postmodern doktrinin belirleyici faktörlerinden biri metinlerarasılık yöntemi olmuştur. İlk başta yazınsal alanda kendini gösteren ve postmodern dönem edebiyatının en önemli unsurlarından biri haline gelen metinlerarasılık kavramı ilerleyen yıllarda doğal olarak sanatın diğer alanlarına da yayılmış ve sinemasal çağda yaşadığımız bu dönemde filmlere de farklı bir dil ve boyut kazandırmıştır. Metinlerarasılık, zaman ve mekan ayrımı yapılmaksızın, yaşamın ve sanatın her alanında görülebilen farklı metinler arasındaki ilişkiler olarak tanımlanmaktadır. Her eser aynı sanat disiplininde bulunup bulunmamasına bakılmaksızın diğer eserlerden izler taşır. Bu izler, başka bir eserin doğrudan referansları olarak bulunabilir ya da daha örtük bir şekilde yer alabilir. Diğer sanatların bir kombinasyonu niteliğinde bir tür sanat olan ve gelişimini teknolojiye paralel olarak gösteren sinema, yedinci sanat olarak adlandırılmaktadır. Bunun nedeni, diğer altı sanattan sonra ortaya çıkmasının ötesinde, aynı zamanda diğer altı sanat disiplininden de izler taşımasıdır. Dolayısıyla, filmleri analiz ederken filmin birebir veya dolaylı olarak ilişkili olduğu yapitları bulmak bir zorunluluktur. İzleyiciler için metinlerarası yolculuk da ancak bu yakın ilişkili metinlerin ve kaynaklarının tespiti ile mümkün olabilmektedir.

Postmodern filmlerin parçalı yapısı ve çoklu olay örgüsü metinlerarasılığın sinemaya yansıması olarak değerlendirilebilir....Filmin postmodernliğini belirleyen tarafı ise, metinlerarasıllğın film içerisinde yer almasından ziyade metinlerarasılığın kullanım biçimidir. Postmodern filmlerde benzer sanatsal kaygı olarak veya anlamlandırma sürecinde bir öğe olarak değil, kurgulanan oyunun bir parçası, yüzeyselliğin ve eğlencenin tamamlayıcısı olarak metinlerarasılığa rastlanmaktadır. (Kaya \& İspir, 2011, ss. 95-96).

Zamanın koşulları içerisinde göze çarpan yüksek bir bütçeyle çekilmiş olmasının yanı sıra, Türkiye'de gösterime girmesinin ardından yüksek hasılat elde eden G.O.R.A. ve A.R.O.G. filmleri , daha çok Türk göçmenlerin ağırlıklı olarak bulunduğu Avrupa ülkeleri başta olmak üzere, Türkiye dışındaki yabancı sinemalarda da gösterim imkanı yakalamıştır. G.O.R.A. ve A.R.O.G. filmleri Türk sinema tarihindeki ilk bilimkurgu denemesi olmamasına rağmen, gerek Hollywood film sektörünün türündeki en popüler filmleriyle kurduğu metinlerarası bağ olsun gerekse yerli filmlere yaptığı gönderme ve yerel unsurları yabancı kültürün öğeleriyle harmanlayarak ustalıkla yarattı̆̆ı komedi ile bilimkurgu macera temelli bir komedi filmi olması bakımından ilktir denilebilir. Hem G.O.R.A. hem de A.R.O.G. Hollywood filmleri ve Türk sinemasından çeşitli örnekleri referans noktası olarak alarak macera-bilim kurgu temeline yerleştirilmiş birer komedi filmi olma özeliğini taşımaktadır. İncelemeye konu olan bu iki filmde diğer görsel-işitsel metinlerle yer yer eleştirel, yer yer yalnızca güldürü amaçlı kurulmuş olan metinlerarası bağlar, birçok sahnede iyi bir sinema kültürüne sahip izleyici kitlesince kolaylıkla algılanabilecek netlikte olup, bir metnin diğer metinler aracıllı̆ıyla yaratıcı ancak özgün sayılamayacak bir biçimde hayat bulmasını örneklendirmektedir.

\section{Kaynakça}

Aktaş, S. (2011). Bir Yeni Roman Uyarlaması Olan "Saatler" Filminde Metinlerarasılık ve Göstergeler Arasılık. Yüksek Lisans Tezi, İstanbul: T.C. İstanbul Kültür Üniversitesi Sosyal Bilimler Enstitüsü. 
Aktulum, K. (2000). Metinlerarası İlişkiler. Ankara:Öteki Yayınları.

Aktulum, K. (2011). Metinlerarasılı/ Göstergelerarasıllk. Ankara: Kanguru Yayınları.

Allen, G. (2000). Intertextuality. London: Graham Allen Presses.

Allen, G.(2011). Intertextuality, The New Critical Idiom. London Routledge.

Bakhtin, M. (1981). The Dialogic Imagination: Four Essays, Michael Holquist (ed.), Caryl Emerson \& Michael Holquist (trans.). Austin: University of Texas Press.

Bakhtin M. (1986). Speech Genres and Other Late Essays, Vern W. McGee (trans.), Caryl Emerson \& Michael Holquist (eds.). Austin: University of Austin Press.

Bars, M. E. (2013). “Metinlerarası İlişkiler Bağlamında Oğuz Ka- ğan Destanı’na Bir Bakış”. Uluslararası Türkçe Edebiyat Kültür Eğitim Dergisi, 2(4), 181-197.

Charaudeau,P.; Maingueneau, D. (2004). Dicionário de análise do discurso. Trad. Fabiana Komesu (Coord.). São Paulo: Contexto.

Kristeva, J. (1986). The Kristeva Reader, Toril Moi (ed.). Oxford: Blackwell.

Ott, B. , Walter, C. (2000). “Intertextuality: Interpretive Practice and Textual Strategy”. Critical Studies in Media Communication, 17(4), 429-446.

Öğeyik, M. C. (2008). Metinlerarasılık ve Yazın Eğitimi. Ankara: Anı Yayıncılık

Önal, A. (2013). "Metinlerarasılık Bağlamında Müzikal Metinlerarasılık (Müziklerarasılık)”. İdil, 2 (10), 105-115

Roland, B. "The Theory of the Text" [1973] in Robert Young, ed. Untying the Text: A Post Structuralist Reader. Routledge, 1981, 31-47

Yllmaz, C. (Yapımcı) \& Sorak, O.F. (Yönetmen). (2004). G.O.R.A). [Sinema Filmi]. Türkiye: BKM, Warner Bros.

Yılmaz, C. (Yapımcı), \& Sorak, O.F. (Yönetmen). (2008). A.R.O.G). [Sinema Filmi]. Türkiye: UIP Filmcilik. 